\title{
NEUROCOGNITIVE CONSEQUENCES OF CHRONIC CANNABIS USE: A SYSTEMATIC REVIEW AND META-ANALYSIS
}

Pedro Rafael Figueiredo ${ }^{1^{*}}$, Serenella Tolomeo ${ }^{2,3^{*}}$, J. Douglas Steele $^{3}$, Alexander Baldacchino ${ }^{2}$

1. Hospital Garcia de Orta, Child and Adolescent Psychiatry, Almada, Portugal

2. University of St. Andrews, School of Medicine, Division of Population and Behavioural Science, Fife, Scotland, UK

3. University of Dundee, School of Medicine, Division of Imaging Science and Technology, Dundee, Scotland, UK

*BOTH AUTHORS CONTRIBUTED EQUALLY TO THIS MANUSCRIPT

Corresponding Author: A. Baldacchino, University of St. Andrews, School of Medicine, Division of Population and Behavioural Science, North Haugh, KY169FT, St. Andrews, Fife, Scotland, UK

Email Address: amb30@st-andrews.ac.uk

Contact Address: University of St. Andrews, School of Medicine, Division of Population and Behavioural Science, North Haugh, KY169FT, St. Andrews, Fife, Scotland, UK 


\begin{abstract}
Cannabis is currently the most used illicit substance in the world with a global widespread distribution. Although its acute neurocognitive effects on human behaviour have been reported, there is a lack of robust analysis investigating the link, if any, between chronic cannabis use and neurocognitive function. A systematic review of the literature was conducted in order to identify relevant studies published from 2010 to 2019. A meta-analysis was performed on 13 selected studies testing performance of chronic cannabis users compared with non-users in six different neurocognitive domains. There was a low cross-sectional association between neurocognitive impairments and chronic cannabis use in cognitive impulsivity, cognitive flexibility, attention, short-term memory and long-term memory. No association was found between chronic cannabis use and motor impulsivity. By analysing a specific target population with strict inclusion criteria, these findings provide inconclusive evidence that there are cognitive impairments associated with chronic cannabis use. Future research is needed to determine if the findings of this meta-analysis are biased by the methodological limitations encountered.
\end{abstract}

KEYWORDS: CANNABIS; Chronic CANNABIS Use; NeURopsychology; IMPULSIVITY; Memory; Intelligence; Attention; Cognitive Flexibility; Meta-Analysis. 


\section{Introduction}

Cannabis is the most widely cultivated, trafficked and used illicit drug, with an estimated 147 million people (2.5\% of the world population) consuming it (WHO, 2019). It contains several chemical compounds, including cannabinoids, terpenoids, flavonoids and alkaloids. The cannabinoids are the most psychoactive constituent with more than 100 different ingredients described in the literature (Andre et al., 2016, Bonini et al., 2018, Curran et al., 2016). So far, most of the research has focused on the two most prominent cannabinoids: $\Delta^{9}$-tetrahydrocannabinol $\left(\Delta^{9}\right.$ THC) and cannabidiol (CBD), describing a range of opposing effects of these substances on human brain receptors during the acute phase of consumption (Atakan, 2012, Curran et al., 2016, Englund et al., 2013). It is argued that $\Delta^{9}-\mathrm{THC}$ is linked with impaired learning, psychosis-like events and anxiety, whereas CBD enhances learning and has anti-psychotic and anxiolytic properties (Curran et al., 2016, D'Souza et al., 2004, Das et al., 2013, Leweke et al., 2012, McGuire et al., 2018).

Currently, there is also increasing evidence that acute cannabis use is associated with other neurocognitive impairments in decision-making, such as speed of processing, sustained attention, verbal fluency and executive functioning (Bartholomew et al., 2010, Becker et al., 2014, Gonzalez et al., 2012, Grant et al., 2012, Griffith-Lendering et al., 2012, Huestegge et al., 2010, Lorenzetti et al., 2019, Nusbaum et al., 2017). However, studies investigating persistent neurocognitive impairments, if any, due to chronic cannabis exposure are comparatively scarce inhibiting definitive conclusions (Broyd et al., 2016, Crean et al., 2011, Schreiner and Dunn, 2012). Previous reviews have reported that chronic use of cannabis impacts on cognitive functioning in several domains in adolescents and young adults (i.e. episodic memory, sustained attention, decision making, psychomotor speed, executive functioning, new learning) (Broyd et al., 2016, Curran et al., 2016, Ganzer et al., 2016, Lisdahl et al., 2014, Lubman et al., 2015). A meta-analysis performed by Grant and colleagues (2003) reported no substantial effect $(d,-0.16)$ of long-term cannabis consumption on neurocognitive functioning (Grant et al., 2003). Similarly, 
another meta-analysis published by Schreiner and Dunn (2012) indicated a small neurocognitive impairment effect $(d,-0.29)$ due to chronic cannabis use that persists after acute intoxication particularly on learning and memory, attention and motor functioning (Schreiner and Dunn, 2012). The same authors argued for no significant effect on neurocognitive performance after a period of abstinence of at least 25 days (Schreiner and Dunn, 2012). A recent meta-analysis by Scott and colleagues (2018) also concluded a small effect size $(d,-0.25)$ for neurocognitive impairments in frequent and/or heavy cannabis users, with the largest effects in learning and memory, executive functioning, speed of processing, and attention (Scott et al., 2018).

Although prior meta-analysis provided a quantitative association between chronic cannabis use and neurocognitive impairments, caution is required in interpreting these results. This is mainly due to methodological limitations in the heterogenicity of the studied population and the neurocognitive tasks used, the operational definition of "chronic use" and the lack of clear specification of the abstinence period, if any, prior to testing.

We aimed to further analyse the potential association between chronic cannabis use and neurocognitive impairments by addressing some of the previous methodological limitations in previous reviews focusing on individuals with an age of 18 years or older. Stricter inclusion criteria and a clearly delineated specific period of non-use for each group before the day of testing was used. Furthermore, following similar studies in the field of nicotine (Conti et al., 2019) and opioids (Baldacchino et al., 2012, Baldacchino et al., 2017), standardised differential tasks were used to quantify cognitive impairments.

\section{Literature search}

This review was conducted according to the Meta-analysis of Observational Studies in Epidemiology (MOOSE) guidelines (Stroup et al., 2000) and the Preferred Reporting Items for Systematic review and Meta-Analysis (PRISMA) guidelines (Liberati et al., 2009). 
To meet the required inclusion criteria, all studies had to describe human participants with an age of 18 years or older, experiencing chronic cannabis use and/or a cannabis dependency diagnosed operationally by Diagnostic and Statistical Manual of Mental Disorders (APA, 2013) criteria. A period of non-use was defined as individuals who have not smoked cannabis for at least 12 hours to explicitly avoid the acute effects of cannabis consumption. There is evidence that the psychotropic effects of the drug starts within seconds to minutes and lasts from 2 to 6 hours, reaching a maximum at 12 hours depending on dose and frequency of use (Colizzi and Bhattacharyya, 2018, Grotenhermen, 2003, Moody, 2012). The comparison group was defined as healthy participants who (a) never used cannabis, (b) did not use cannabis for more than a year and/or (c) used cannabis less than 50 times in their lifetime. Studies where included if they reported at least one standardized neurocognitive test, with name and/or description of the task. Case control, longitudinal, and/or cross-sectional studies were included. Baseline data were used for longitudinal studies. Finally, studies were included if cannabis was the primary drug of interest and the manuscripts were published in English, Spanish, Portuguese and Chinese.

The exclusion criteria were the following:

(a) Cohorts including participants under 18 years of age.

(b) Cohorts including participants with a current illicit polydrug use and dependence.

(c) Cohorts including participants with a diagnosis of psychiatric or neurological illnesses.

(d) Cohorts including participants with alcohol dependence.

(e) Cohorts including participants with any history of serious head injury.

(f) Studies focusing on structural or functional neuroimaging parameters as a primary outcome.

(g) Studies in which cannabis users were not asked to abstain prior to testing.

(h) Studies with no healthy non-smoking controls as comparator groups. 
(i) Studies that did not provide neurocognitive scores that could be used to derive an effect size (d), (such as means and standard deviation) (Wolf, 1986)

Study selection was performed between January 2010 and January 2019 to identify relevant papers published during the last 8 years in peer-reviewed journals. A computer-based literature search was conducted using the following databases: PubMed (NLM), Embase (Elsevier), Ovid MEDLINE, SciELO (FAPESP-BIREME), Baidu Scholar (Baidu-Inc.) and CNKI (Tsinghua-University). The search terms used were: marijuana OR marihuana OR THC* OR cannabi* AND neurocog * OR neuropsy* OR cognit* OR assess* OR abilit* OR process* OR intelligen* OR attent* OR memory OR learn* OR executive function* OR impair* AND residual OR long-term OR chronic OR lasting $O R$ persisting $O R$ non-acute. The term neurocognitive/neuropsychological was then replaced with different terms describing cognitive domains and names of a list of specific cognitive tests (Baldacchino et al., 2017). These included "Digit Span", "Rapid Visual Information Processing", "Letter Cancellation Test", "Reaction Time", "Digit Symbol Substitution Test", "Symbol Digit Modalities Test", "Cannabis Stroop Task", "Hopkins Verbal Learning Test", "Spatial Working Memory", "California Verbal Learning Test", "Controlled Oral Word Association Test", "Two Back Test", "Video Prospective Memory Task", "Finger Tapping Test", "Grooved Pegboard", "Rey Auditory Verbal Learning Test", "lowa Gambling Task", "Go-Stop Task", "Stroop Color Word Task", "Wisconsin Card Sorting Test", "Trail Making Test"

All of the identified abstracts from the electronic search were independently reviewed by the authors allowing selecting eligible studies for the systematic review and meta-analysis. Finally, the references of the selected papers were examined and a "snowballing" technique employed in order to identify further relevant studies. Several studies did not provide neurocognitive scores on the published papers. In order to have access to the relevant data, six authors were contacted and four replied back, four studies were excluded (two studies due to lack of information and the other two studies due to unmet selection criteria). 


\section{Analysis}

Standard meta-analytic techniques were employed to estimate the consequences of chronic cannabis use on eight neurocognitive domains, such as Cognitive Flexibility, Cognitive Impulsivity, Motor Impulsivity, Non-Planning Impulsivity, Attention, Short-Term Memory, Long-Term Memory and Emotional Cognition. The identification of such domains was performed similarly to previous meta-analytic reviews of cross-sectional studies by Baldacchino, Conti and colleagues (Baldacchino et al., 2012, Baldacchino et al., 2017, Conti et al., 2019) (Tables 1-3).

Since different neurocognitive scales for each domain were employed in the studies, the standardized mean difference statistic was used to measure effect size (Sutton et al., 2000). In case of substantial heterogeneity, a random effect model was preferred (Quintana and Minami, 2006, Hedges and Verea, 1998). Study heterogeneity was assessed by Cochran's Q and $I^{2}$ index (Cochran, 1950, Higgins et al., 2003).

Eligible research studies reporting means and standard deviations from each group were assembled into a database and computed through the Comprehensive Meta-Analysis Version III software (2017). The statistical significance level was $p=0.05$ and in $Q$ statistics $p=0.10$. A large effect size was defined by a value of 0.80 , a medium effect size by a value of 0.50 , and a small effect size by a value of 0.20 (Cohen, 1988).

In order to identify possible associations between each of the continuous moderator variables (age, duration of use, period of non-use and dose) and the effect size, we considered using a meta-regression (Thompson and Higgins, 2002). However, due to lack of information in the selected studies, the meta-regression was not feasible. 


\subsection{Publication Bias}

Studies with statistically significant results are more often published in comparison to studies with non-significant and/or negative results (Dickersin, 2005, Hedges, 1989). Thus, we considered the possibility that the selected studies were biased affecting the results of the analysis. To assess publication bias a visual inspection of funnel plots was performed in addition to determination of the Fail Safe N (Orwin, 1983). Fail Safe $N$ corresponds to the number of missing studies that would permit to determine how many of these studies need to be added to a metaanalysis in order to bring the overall result from significant to non-significant.

\subsection{Assessment of study quality}

The quality of the papers included in this review was evaluated and graded using the Scottish Intercollegiate Guidelines Network (NHS, 1993). Studies were classified as "unmatched", "matched on demographic variables", "matched on behavioural and demographic variables", "longitudinal measurements", "matched with longitudinal study". The quality of the studies was assessed by two authors (PRF, ST and $\mathrm{AB}$ ) as we aimed to avoid bias.

\section{Results}

Computer-based searching yielded 4839 references. After removal of duplicates, the search terms yielded 2827 unique studies and after screening for relevance, 2630 studies were excluded. The remaining 197 studies were assessed for eligibility by title and abstract inspection, eliminating 131 papers. The remaining 66 studies were retrieved for further assessment utilizing the inclusion and exclusion criteria. There were 12 cross-sectional studies and 1 longitudinal study included in this meta-analysis (Figure 1). None of the identified studies recruited non-smoking chronic cannabis users. 
From the 13 studies, 6 studies were classified as "matched on demographic variables", 5 studies as "unmatched" and 2 as "matched on behavioural and demographic variables". The five studies that were graded as "unmatched" were included in the quantitative synthesis in order to avoid sample size reduction and consequent low statistical power of the meta-analysis (Hedges and Pigott, 2004) as their methodologies didn't present major flaws.

Furthermore, most of the studies contained reported data from different comparator groups (e.g. "experimenters", "light cannabis users", "former heavy users", "synthetic cannabis users", "recreational cannabis users") so only suitable comparator groups were included, in accordance with established criteria. The excluded comparator groups are presented in Table 4.

There were 13 selected studies, with 1382 participants, including 499 chronic cannabis users and 883 comparison participants who had minimal or no cannabis use in their lifetime. The reported Mean (Standard Deviation) age of cannabis users varied from 19 (5.0) years (Bartholomew et al., 2010) to 27.5 (5.4) years old (Cohen et al., 2017). Comparison participants had a mean age range of 19 (3.0) years (Bartholomew et al., 2010) to 26.2 (10.7) years old (Morgan et al., 2010). The lowest reported duration of cannabis use was 3 years (Bartholomew et al., 2010) and the highest was 15.2 years (Becker et al., 2014).

Studies were mainly conducted in the United States, Europe and Australia. It was not possible to extract duration of cannabis use (in years) in 6 of the studies due to lack of information. The demographic characteristics and the clinical information of the selected studies are shown in Tables 5 and 6.

\subsection{Neurocognitive domains}

Twenty-eight effect sizes measurements were conducted from the selected studies. Analysis on the Non-Planning Impulsivity and Emotional Cognition was not possible since there was only one study identified for each neurocognitive domain (Bayrakçı et al., 2015, Becker et al., 2014). Presence of publication bias for testing all 
cognitive domains was present. These results and related effect sizes are shown in Table 7.

For Cognitive Impulsivity a significant and small effect size of 0.30 was found in favour of the control group $(z=2.11, p<0.05)$ showing a slight tendency for chronic cannabis users to opt for small immediate rewards over larger delayed rewards comparing to non-users. Results of $Q$ and $I^{2}$ tests indicated low heterogeneity between the 4 pooled studies $\left(Q=4.76, p=0.19 ; I^{2}=36.97\right)$ (Figure 2$)$.

For Motor Impulsivity a non-significant effect size of 0.05 was detected in favour of the control group $(z=0.37, p=0.72)$ revealing no association between chronic cannabis use and the ability to suppress emotional, cognitive and behavioural responses. Results of $\mathrm{Q}$ and $I^{2}$ tests indicated homogeneity between the 2 pooled studies $\left(Q=0.001, p=0.98 ; I^{2}=0.00\right)$ (Figure 3 ).

For Cognitive Flexibility a significant and small effect size of 0.33 was found in favour of the control group $(z=3.04, p<0.005)$ showing an impaired capacity for chronic cannabis users to make appropriate behavioural decisions while switching between cognitive processes. Results of $Q$ and $I^{2}$ tests indicated very low heterogeneity between the 6 pooled studies $\left(Q=5.22, p=0.39 ; I^{2}=4.29\right.$ ) (Figure 4).

For Attention a significant and small effect size of 0.16 was identified in favour of the control group $(z=2.27, p<0.05)$ revealing a slightly better ability for nonusers to reject irrelevant information while attending to relevant input and to detect unpredictable signals during prolonged periods of time, in contrast to chronic cannabis users. Results of $Q$ and $I^{2}$ tests indicated low heterogeneity between the 6 pooled studies $\left(Q=5.52, p=0.36 ; I^{2}=9.48\right)$ (Figure 5).

For Short-term Memory a significant medium effect size of 0.48 was found in favour of the control group $(z=5.63, p<0.001)$ showing an impairment for chronic cannabis users to recognize and recall information presented directly or shortly in comparison to non-users. Results of $Q$ and $I^{2}$ tests indicated homogeneity between the 6 pooled studies $\left(Q=4.17, p=0.53 ; I^{2}=0.00\right)$ (Figure 6).

For Long-term Memory a significant effect size of 0.43 was detected in favour of the control group $(z=3.12, p<0.005)$ representing a better ability for non-users to retain implicit and explicit information over longer periods of time compared to 
chronic cannabis users. Results of $Q$ and $I^{2}$ tests indicated moderate heterogeneity between the 4 pooled studies $\left(Q=5.65, p=0.13 ; I^{2}=46.92\right)$ (Figure 7$)$.

\section{Discussions}

\subsection{Key findings}

We conducted a quantitative and systematic review of the literature on the impact of chronic cannabis use on neurocognitive functioning. Although the effect sizes and functional consequences may vary, the meta-analysis revealed an association between chronic cannabis use and cognitive impairment in a broad range of functional domains such as cognitive impulsivity, cognitive flexibility, attention, short-term memory and long-term memory. The magnitude of the effect size was higher in long-term memory domain and lower in attentional domain but still low in size. Fail Safe $\mathrm{N}$ results are not sufficiently high to exclude possible publication bias (Table 7).

Small effect sizes were observed in all neurocognitive domains. A limited association was found between cannabis use and neurocognitive deficits, and memory were linked to chronic cannabis use. These findings contrasts with several neuroimaging studies that reported the impact of cannabis-related memory deficits associated with putative neural substrates, such as hippocampus (Orr et al., 2019, Ashtari et al., 2011, Jager et al., 2007, Smith et al., 2014, Smith et al., 2015). These results are consistent with a previous meta-analysis conducted by Scott and colleagues (2018), that revealed a similar effect size magnitude across all cognitive domains (mean $d,-0.33$ to -0.21 ) in a young heavy/frequent cannabis users' population. Our findings are also in line with previous meta-analysis that suggested small effect sizes across learning and memory domains with long-term, regular cannabis consumption (Grant et al., 2003, Schreiner and Dunn, 2012). 
Collectively, our analysis indicates a limited association between chronic cannabis use and cognitive impairments in adults, with moderate heterogeneity between the 28 pooled studies.

\subsection{Strengths and Limitations}

The inclusion and exclusion criteria were stringent, thus aiding the elimination of confounding factors such as concomitant alcohol and polydrug abuse, and no current psychiatric or neurological disorder. In this review, cannabis users were well matched with healthy controls. Notably, gender, age, educational level and socioeconomic status were not included as covariates, which could impact on cognitive functioning (Mani et al., 2013, Murman, 2015, Piumatti et al., 2018, Salthouse, 2009). Comparing with a recent meta-analysis reported by Scott and colleagues (2018), who evaluated cognitive impairments due to chronic cannabis use on adolescent and young adults, our study only included adult participants. Studies targeting adolescents were excluded as young people are particularly vulnerable to the effects of addictive drugs and their brain is not fully developed (Bernheim et al., 2013, Crews et al., 2007, Winters and Arria, 2011). A recent systematic review of human and animal studies elucidates the age-related impact of cannabis use and cognition. Importantly, Gorey and colleagues found that age-dependent effect of cannabis is associated with cannabis use history and intoxication state (Gorey et al., 2019). Another strength of our work was to use rigorous selection criteria for included participants. We only included studies recruiting comparison groups of individuals who had never used cannabis or who had minimal use in their lifetime (less than 50 times) to attenuate a potential cumulative effect of cannabis use in the comparator group. This is in contrast to previous meta-analysis' (Scott et al., 2018, Schreiner and Dunn, 2012) methodology, where the definition for the comparison group was not explicit. In addition, contrary to these both studies, a strict period of at least 12 hours without using cannabis was defined in the users' group to focus our analysis on long-term effects of cannabis use, excluding possible confounding factors related to acute effects of the drug on the day of testing. There is evidence that some 
cognitive functioning may recover after abstinence, but reported results are not consistent due to different methodologies (Bosker et al., 2013, Hanson et al., 2010, Hooper et al., 2014, Meier et al., 2012, Tait et al., 2011).

Confounding factors such as educational status, concomitant tobacco smoking or alcohol use were considered by most of the included studies. The mean dose and frequency of use varied throughout the selected studies, including imprecise quantitative measurements (i.e. joints, smoking episodes, grams, hits per day, days per month, days per year). This could be an important confounding factor as several studies reported a positive relationship between the amount of drug exposure and cognitive outcomes (Auer et al., 2016, Gruber et al., 2012, Lisdahl and Price, 2012, Meier et al., 2012). To reduce this discrepancy, we used DSM-5 diagnostic criteria for all included participants, defining chronic cannabis use as continuous and recurrent cannabis consumption as occurring within a 12-month period. A recent report from the European Monitoring Centre for Drugs and Drug Addiction (EMCDDA, 2018a) mentions a large increase in the potency of cannabis, contributing to a great variability regarding cannabis ingredients and concentrations consumed by each individual. Dose, frequency of use, duration and age of onset of use all interact to mediate the neurocognitive impairments of the substance (EMCDDA, 2018a). Our analysis found mixed effects regarding the association between parameters of cannabis use and neurocognitive impairments. Future studies should attempt to measure the diverse cannabis compounds in each consumed drug.

Other possible limiting factors include the lack of information on participants' neurodevelopmental history and the manifestation of previous neuropsychiatric conditions that may predispose to the development of substance misuse and dependency (Dalley et al., 2007, Gouzoulis-Mayfrank et al., 2000). Thus, an important question is whether cognitive impairments identified were simply a consequence of prolonged drug use and/or a premorbid vulnerability to drug dependency (Gonzalez et al., 2012, de Wit, 2009, Goldstein et al., 2006). The lack of information regarding the impact of cannabis exposure on important factors such as gender and age of the participants could also be considered as another limitation of this meta-analysis. In fact, it wasn't possible to draw any significant conclusion on gender differences but some of the included studies have reported that men scored 
higher on impulsivity measures and poorer on psychomotor speed in comparison with females (Griffith-Lendering et al., 2012, Lisdahl and Price, 2012). These factors should be taken in consideration by future studies.

\subsection{Clinical Relevance}

During the past decade, the prevalence of cannabis use in Europe has remained continuously high by historical standards, and recent increases have been noted in some EU countries (EMCDDA, 2018a). However, public perception tends to view cannabis as a harmless drug, frequently disregarding its potential long-term health problems (Carliner et al., 2017, Lorenzetti et al., 2019, Volkow et al., 2014). Additionally, several studies have indicated a potential therapeutic effect of cannabinoids for some selected illnesses (Andreae et al., 2015, Devinsky et al., 2016, Kafil et al., 2018, Romero-Sandoval et al., 2017) with countries recently legalising the medicinal and recreational use of this substance (EMCDDA, 2018b, Knöss et al., 2019, Millar et al., 2019).

The present meta-analysis identified a cross-sectional association between chronic cannabis use and neurocognitive impairments within specific memory domains when compared to non-cannabis users. Cognitive impairments are negatively associated with quality of life measures (Kurz et al., 2003, Lindeboom and Weinstein, 2004, Logsdon et al., 2002, Tarawneh and Holtzman, 2012) making individuals more susceptible to adverse life events and/or to the development of new psychiatric conditions (Schulte and Hser, 2014, GBD, 2018). Pre-treatment neurocognitive assessments and personalized Cognitive Rehabilitation Treatments (CRTs) could be useful in cannabis users wishing to stop consumption as these initiatives could support an improvement in cognitive function and prevent relapse (Rezapour et al., 2015). 


\section{Conclusion}

A systematic review and meta-analysis were conducted to study the impact of chronic cannabis use on neurocognitive functioning. We found a cross-sectional association between chronic cannabis use and impairments in six neurocognitive domains, including memory function, cognitive impulsivity, cognitive flexibility and attention. The current quantitative analysis does not quantify persistence impairments, but these results should not discourage the provision of specific therapeutic procedures, which may ultimately improve cognitive functioning in vulnerable chronic cannabis users. In that context, researchers and practitioners should also consider the importance of biopsychosocial effects associated with chronic cannabis use and help to create preventative measures against it if needed.

Future studies should further investigate specific aspects of cannabis use in carefully defined individuals (e.g. dose, frequency and cannabinoid content) and try to evaluate whether cognitive impairments due to cannabis exposure would remit after an extended period of non-use. Such work would promote better understanding of the impact of cannabis use on each individual.

\section{Conflicts of Interests}

$A B$ has no conflicts of interest with regard to the current work. However unrelated to this project he has received educational grants from Schering Plough, Merck Serono, Reckitt Benckiser and Indivior. DS has no conflicts of interest with regard to the current work. However unrelated to this project he has received research funding via an honorarium associated with a lecture from Wyeth and funding from Indivior. ST has no conflicts of interest with regard to the current work. However unelated to this project she has received funding from Indivior, Merck Serono and Lundbeck. PRF has no conflicts of interest. 


\section{Funding}

This research did not receive any specific grant from funding agencies in the public, commercial, or not-for-profit sectors.

\section{Acknowledgement}

We thank Dr Ajay Shah for his contribution on literature search. 


\section{References}

ANDRE, C. M., HAUSMAN, J. F. \& GUERRIERO, G. 2016. Cannabis sativa: The Plant of the Thousand and One Molecules. Front Plant Sci, 7, 19.

ANDREAE, M. H., CARTER, G. M., SHAPARIN, N., SUSLOV, K., ELLIS, R. J., WARE, M. A., ABRAMS, D. I., PRASAD, H., WILSEY, B., INDYK, D., JOHNSON, M. \& SACKS, H. S. 2015. Inhaled Cannabis for Chronic Neuropathic Pain: A Meta-analysis of Individual Patient Data. J Pain, 16, 1221-1232.

APA, AMERICAN PSYCHIATRIC ASSOCIATION 2013. Diagnostic and statistical manual of mental disorders: DSM-5, Arlington, VA, American Psychiatric Association.

ASHTARI, M., AVANTS, B., CYCKOWSKI, L., CERVELLIONE, K. L., ROOFEH, D., COOK, P., GEE, J., SEVY, S. \& KUMRA, S. 2011. Medial temporal structures and memory functions in adolescents with heavy cannabis use. J Psychiatr Res, 45, 1055-66.

ATAKAN, Z. 2012. Cannabis, a complex plant: different compounds and different effects on individuals. Ther Adv Psychopharmacol, 2, 241-54.

AUER, R., VITTINGHOFF, E., YAFFE, K., KÜNZI, A., KERTESZ, S. G., LEVINE, D. A., ALBANESE, E., WHITMER, R. A., JACOBS, D. R., SIDNEY, S., GLYMOUR, M. M. \& PLETCHER, M. J. 2016. Association Between Lifetime Marijuana Use and Cognitive Function in Middle Age: The Coronary Artery Risk Development in Young Adults (CARDIA) Study. JAMA Intern Med, 176, 352-61.

BAIDU-INC. Baidu Scholar [Online]. Available: http://xueshu.baidu.com/.

BALDACCHINO, A., ARMANYOUS, M., BALFOUR, D. J., HUMPHRIS, G. \& MATTHEWS, K. 2017. Neuropsychological functioning and chronic methadone use: $A$ systematic review and meta-analysis. Neurosci Biobehav Rev, 73, 23-38.

BALDACCHINO, A., BALFOUR, D. J., PASSETTI, F., HUMPHRIS, G. \& MATTHEWS, K. 2012. Neuropsychological consequences of chronic opioid use: a quantitative review and meta-analysis. Neurosci Biobehav Rev, 36, 2056-68.

BARTHOLOMEW, J., HOLROYD, S. \& HEFFERNAN, T. M. 2010. Does cannabis use affect prospective memory in young adults? J Psychopharmacol, 24, 241-6.

BAYRAKÇI, A., SERT, E., ZORLU, N., EROL, A., SARIÇIÇEK, A. \& METE, L. 2015. Facial emotion recognition deficits in abstinent cannabis dependent patients. Compr Psychiatry, 58, 160-4.

BECKER, M. P., COLLINS, P. F. \& LUCIANA, M. 2014. Neurocognition in college-aged daily marijuana users. J Clin Exp Neuropsychol, 36, 379-98.

BERNHEIM, A., HALFON, O. \& BOUTREL, B. 2013. Controversies about the enhanced vulnerability of the adolescent brain to develop addiction. Front Pharmacol, 4, 118.

BONINI, S. A., PREMOLI, M., TAMBARO, S., KUMAR, A., MACCARINELLI, G., MEMO, M. \& MASTINU, A. 2018. Cannabis sativa: A comprehensive ethnopharmacological review of a medicinal plant with a long history. J Ethnopharmacol, 227, 300315.

BOSKER, W. M., KARSCHNER, E. L., LEE, D., GOODWIN, R. S., HIRVONEN, J., INNIS, R. B., THEUNISSEN, E. L., KUYPERS, K. P., HUESTIS, M. A. \& RAMAEKERS, J. G. 2013. Psychomotor function in chronic daily Cannabis smokers during sustained abstinence. PLoS One, 8, e53127. 
BROYD, S. J., VAN HELL, H. H., BEALE, C., YÜCEL, M. \& SOLOWIJ, N. 2016. Acute and Chronic Effects of Cannabinoids on Human Cognition-A Systematic Review. Biol Psychiatry, 79, 557-67.

CARLINER, H., BROWN, Q. L., SARVET, A. L. \& HASIN, D. S. 2017. Cannabis use, attitudes, and legal status in the U.S.: A review. Prev Med, 104, 13-23.

COCHRAN, W. G. 1950. The comparison of percentages in matched samples. Biometrika, 37, 256-66.

COHEN, J. 1988. Statistical Power Analysis for the Behavioral Sciences, New York, L. Erlbaum Associates.

COHEN, K., KAPITÁNY-FÖVÉNY, M., MAMA, Y., ARIELI, M., ROSCA, P., DEMETROVICS, Z. $\&$ WEINSTEIN, A. 2017. The effects of synthetic cannabinoids on executive function. Psychopharmacology (Berl), 234, 1121-1134.

COLIZZI, M. \& BHATTACHARYYA, S. 2018. Cannabis use and the development of tolerance: a systematic review of human evidence. Neurosci Biobehav Rev, 93, 1-25.

CONTI, A. A., MCLEAN, L., TOLOMEO, S., STEELE, J. D. \& BALDACCHINO, A. 2019. Chronic tobacco smoking and neuropsychological impairments: A systematic review and meta-analysis. Neurosci Biobehav Rev, 96, 143-154.

COUSIJN, J., WATSON, P., KOENDERS, L., VINGERHOETS, W. A., GOUDRIAAN, A. E. \& WIERS, R. W. 2013. Cannabis dependence, cognitive control and attentional bias for cannabis words. Addict Behav, 38, 2825-32.

CREAN, R. D., CRANE, N. A. \& MASON, B. J. 2011. An evidence based review of acute and long-term effects of cannabis use on executive cognitive functions. J Addict Med, 5, 1-8.

CREWS, F., HE, J. \& HODGE, C. 2007. Adolescent cortical development: a critical period of vulnerability for addiction. Pharmacol Biochem Behav, 86, 189-99.

CURRAN, H. V., FREEMAN, T. P., MOKRYSZ, C., LEWIS, D. A., MORGAN, C. J. \& PARSONS, L. H. 2016. Keep off the grass? Cannabis, cognition and addiction. Nat Rev Neurosci, 17, 293-306.

CUTTLER, C., MCLAUGHLIN, R. J. \& GRAF, P. 2012. Mechanisms underlying the link between cannabis use and prospective memory. PLoS One, 7, e36820.

D'SOUZA, D. C., PERRY, E., MACDOUGALL, L., AMMERMAN, Y., COOPER, T., WU, Y. T., BRALEY, G., GUEORGUIEVA, R. \& KRYSTAL, J. H. 2004. The psychotomimetic effects of intravenous delta-9-tetrahydrocannabinol in healthy individuals: implications for psychosis. Neuropsychopharmacology, 29, 1558-72.

DAHLGREN, M. K., SAGAR, K. A., RACINE, M. T., DREMAN, M. W. \& GRUBER, S. A. 2016. Marijuana Use Predicts Cognitive Performance on Tasks of Executive Function. J Stud Alcohol Drugs, 77, 298-308.

DALLEY, J. W., FRYER, T. D., BRICHARD, L., ROBINSON, E. S., THEOBALD, D. E., LÄÄNE, K., PEÑA, Y., MURPHY, E. R., SHAH, Y., PROBST, K., ABAKUMOVA, I., AIGBIRHIO, F. I., RICHARDS, H. K., HONG, Y., BARON, J. C., EVERITT, B. J. \& ROBBINS, T. W. 2007. Nucleus accumbens $D 2 / 3$ receptors predict trait impulsivity and cocaine reinforcement. Science, 315, 1267-70.

DAS, R. K., KAMBOJ, S. K., RAMADAS, M., YOGAN, K., GUPTA, V., REDMAN, E., CURRAN, H. V. \& MORGAN, C. J. 2013. Cannabidiol enhances consolidation of explicit fear extinction in humans. Psychopharmacology (Berl), 226, 781-92. 
DE WIT, H. 2009. Impulsivity as a determinant and consequence of drug use: a review of underlying processes. Addict Biol, 14, 22-31.

DEVINSKY, O., MARSH, E., FRIEDMAN, D., THIELE, E., LAUX, L., SULLIVAN, J., MILLER, I., FLAMINI, R., WILFONG, A., FILLOUX, F., WONG, M., TILTON, N., BRUNO, P., BLUVSTEIN, J., HEDLUND, J., KAMENS, R., MACLEAN, J., NANGIA, S., SINGHAL, N. S., WILSON, C. A., PATEL, A. \& CILIO, M. R. 2016. Cannabidiol in patients with treatment-resistant epilepsy: an open-label interventional trial. Lancet Neurol, $15,270-8$.

DICKERSIN, K. 2005. Publication Bias: Recognizing the Problem, Understanding Its Origins and Scope, and Preventing Harm. Publication Bias in Meta-Analysis Prevention, Assessment and Adjustments. West Sussex, England: John Wiley \& Sons Ltd.

ELSEVIER. Embase [Online]. Elsevier. Available: https://www.elsevier.com/solutions/embase-biomedical-research.

EMCDDA, EUROPEAN MONITORING CENTRE FOR DRUGS AND DRUG ADDICTION 2018a. European Drug Report.

EMCDDA, EUROPEAN MONITORING CENTRE FOR DRUGS AND DRUG ADDICTION 2018b. Medical use of cannabis and cannabinoids.

ENGLEWOOD., B. S. 2017. Comprehensive Meta Analysis. 3 ed. New Jersey, US.

ENGLUND, A., MORRISON, P. D., NOTTAGE, J., HAGUE, D., KANE, F., BONACCORSO, S., STONE, J. M., REICHENBERG, A., BRENNEISEN, R., HOLT, D., FEILDING, A., WALKER, L., MURRAY, R. M. \& KAPUR, S. 2013. Cannabidiol inhibits THC-elicited paranoid symptoms and hippocampal-dependent memory impairment. J Psychopharmacol, 27, 19-27.

FAPESP-BIREME. SciELO [Online]. Available: https://www.scielo.org/.

GANZER, F., BRÖNING, S., KRAFT, S., SACK, P. M. \& THOMASIUS, R. 2016. Weighing the Evidence: A Systematic Review on Long-Term Neurocognitive Effects of Cannabis Use in Abstinent Adolescents and Adults. Neuropsychol Rev, 26, 186222.

GBD, ALCOHOL AND DRUG USE COLLABORATORS 2018. The global burden of disease attributable to alcohol and drug use in 195 countries and territories, 19902016: a systematic analysis for the Global Burden of Disease Study 2016. Lancet Psychiatry, 5, 987-1012.

GOLDSTEIN, R., ALIA-KLEIN, N., COTTONE, L. \& VOLKOW, N. 2006. The orbitofrontal cortex in drug addiction. The orbitofrontal cortex. Oxford, UK: Oxford University Press.

GONZALEZ, R., SCHUSTER, R. M., MERMELSTEIN, R. J., VASSILEVA, J., MARTIN, E. M. \& DIVIAK, K. R. 2012. Performance of young adult cannabis users on neurocognitive measures of impulsive behavior and their relationship to symptoms of cannabis use disorders. J Clin Exp Neuropsychol, 34, 962-76.

GOREY, C., KUHNS, L., SMARAGDI, E., KROON, E. \& COUSIJN, J. 2019. Age-related differences in the impact of cannabis use on the brain and cognition: a systematic review. Eur Arch Psychiatry Clin Neurosci, 269, 37-58.

GOUZOULIS-MAYFRANK, E., DAUMANN, J., TUCHTENHAGEN, F., PELZ, S., BECKER, S., KUNERT, H. J., FIMM, B. \& SASS, H. 2000. Impaired cognitive performance in drug free users of recreational ecstasy (MDMA). J Neurol Neurosurg Psychiatry, $68,719-25$. 
GRANT, I., GONZALEZ, R., CAREY, C. L., NATARAJAN, L. \& WOLFSON, T. 2003. Non-acute (residual) neurocognitive effects of cannabis use: a meta-analytic study. J Int Neuropsychol Soc, 9, 679-89.

GRANT, J. E., CHAMBERLAIN, S. R., SCHREIBER, L. \& ODLAUG, B. L. 2012. Neuropsychological deficits associated with cannabis use in young adults. Drug Alcohol Depend, 121, 159-62.

GRIFFITH-LENDERING, M. F., HUIJBREGTS, S. C., VOLLEBERGH, W. A. \& SWAAB, H. 2012. Motivational and cognitive inhibitory control in recreational cannabis users. J Clin Exp Neuropsychol, 34, 688-97.

GROTENHERMEN, F. 2003. Pharmacokinetics and pharmacodynamics of cannabinoids. Clin Pharmacokinet, 42, 327-60.

GRUBER, S. A., SAGAR, K. A., DAHLGREN, M. K., RACINE, M. \& LUKAS, S. E. 2012. Age of onset of marijuana use and executive function. Psychol Addict Behav, 26, 496506.

HANSON, K. L., WINWARD, J. L., SCHWEINSBURG, A. D., MEDINA, K. L., BROWN, S. A. \& TAPERT, S. F. 2010. Longitudinal study of cognition among adolescent marijuana users over three weeks of abstinence. Addict Behav, 35, 970-6.

HEDGES, L. V. 1989. A Practical Guide to Modern Methods of Meta-analysis. National Science Teachers Association. Washington DC, USA: National Science Teachers Association.

HEDGES, L. V. \& PIGOTT, T. D. 2004. The power of statistical tests for moderators in meta-analysis. Psychol Methods, 9, 426-45.

HEDGES, L. V. \& VEREA, J. L. 1998. Fixed-and random-effects models in meta-analysis. Psychological Methods, 3, 9.

HIGGINS, J. P., THOMPSON, S. G., DEEKS, J. J. \& ALTMAN, D. G. 2003. Measuring inconsistency in meta-analyses. BMJ, 327, 557-60.

HOOPER, S. R., WOOLLEY, D. \& DE BELLIS, M. D. 2014. Intellectual, neurocognitive, and academic achievement in abstinent adolescents with cannabis use disorder. Psychopharmacology (Berl), 231, 1467-77.

HUESTEGGE, L., KUNERT, H. J. \& RADACH, R. 2010. Long-term effects of cannabis on eye movement control in reading. Psychopharmacology (Berl), 209, 77-84.

JAGER, G., VAN HELL, H. H., DE WIN, M. M., KAHN, R. S., VAN DEN BRINK, W., VAN REE, J. M. \& RAMSEY, N. F. 2007. Effects of frequent cannabis use on hippocampal activity during an associative memory task. Eur Neuropsychopharmacol, 17, 289-97.

KAFIL, T. S., NGUYEN, T. M., MACDONALD, J. K. \& CHANDE, N. 2018. Cannabis for the treatment of Crohn's disease. Cochrane Database Syst Rev, 11, CD012853.

KNÖSS, W., VAN DE VELDE, M., SANDVOS, C. \& CREMER-SCHAEFFER, P. 2019. Key elements of legal environments for medical use of cannabis in different countries. Bundesgesundheitsblatt Gesundheitsforschung Gesundheitsschutz, 62, 855-860.

KURZ, X., SCUVEE-MOREAU, J., VERNOOIJ-DASSEN, M. \& DRESSE, A. 2003. Cognitive impairment, dementia and quality of life in patients and caregivers. Acta Neurol Belg, 103, 24-34.

LEWEKE, F. M., PIOMELLI, D., PAHLISCH, F., MUHL, D., GERTH, C. W., HOYER, C., KLOSTERKÖTTER, J., HELLMICH, M. \& KOETHE, D. 2012. Cannabidiol enhances 
anandamide signaling and alleviates psychotic symptoms of schizophrenia. Transl Psychiatry, 2, e94.

LIBERATI, A., ALTMAN, D. G., TETZLAFF, J., MULROW, C., GØTZSCHE, P. C., IOANNIDIS, J. P., CLARKE, M., DEVEREAUX, P. J., KLEIJNEN, J. \& MOHER, D. 2009. The PRISMA statement for reporting systematic reviews and meta-analyses of studies that evaluate health care interventions: explanation and elaboration. PLoS Med, 6, e1000100.

LINDEBOOM, J. \& WEINSTEIN, H. 2004. Neuropsychology of cognitive ageing, minimal cognitive impairment, Alzheimer's disease, and vascular cognitive impairment. Eur J Pharmacol, 490, 83-6.

LISDAHL, K. M. \& PRICE, J. S. 2012. Increased marijuana use and gender predict poorer cognitive functioning in adolescents and emerging adults. J Int Neuropsychol Soc, $18,678-88$.

LISDAHL, K. M., WRIGHT, N. E., KIRCHNER-MEDINA, C., MAPLE, K. E. \& SHOLLENBARGER, S. 2014. : The Effects of Regular Cannabis Use on Neurocognition in Adolescents and Young Adults. Curr Addict Rep, 1, 144-156.

LOGSDON, R. G., GIBBONS, L. E., MCCURRY, S. M. \& TERI, L. 2002. Assessing quality of life in older adults with cognitive impairment. Psychosom Med, 64, 510-9.

LORENZETTI, V., CHYE, Y., SILVA, P., SOLOWIJ, N. \& ROBERTS, C. A. 2019. Does regular cannabis use affect neuroanatomy? An updated systematic review and metaanalysis of structural neuroimaging studies. Eur Arch Psychiatry Clin Neurosci, 269, 59-71.

LUBMAN, D. I., CHEETHAM, A. \& YÜCEL, M. 2015. Cannabis and adolescent brain development. Pharmacol Ther, 148, 1-16.

MANI, A., MULLAINATHAN, S., SHAFIR, E. \& ZHAO, J. 2013. Poverty impedes cognitive function. Science, 341, 976-80.

MCGUIRE, P., ROBSON, P., CUBALA, W. J., VASILE, D., MORRISON, P. D., BARRON, R., TAYLOR, A. \& WRIGHT, S. 2018. Cannabidiol (CBD) as an Adjunctive Therapy in Schizophrenia: A Multicenter Randomized Controlled Trial. Am J Psychiatry, 175, 225-231.

MEIER, M. H., CASPI, A., AMBLER, A., HARRINGTON, H., HOUTS, R., KEEFE, R. S., MCDONALD, K., WARD, A., POULTON, R. \& MOFFITT, T. E. 2012. Persistent cannabis users show neuropsychological decline from childhood to midlife. Proc Natl Acad Sci U S A, 109, E2657-64.

MERCURI, K., TERRETT, G., HENRY, J. D., CURRAN, H. V., ELLIOTT, M. \& RENDELL, P. G. 2018. Episodic foresight deficits in regular, but not recreational, cannabis users. J Psychopharmacol, 32, 876-882.

MILLAR, S. A., STONE, N. L., BELLMAN, Z. D., YATES, A. S., ENGLAND, T. J. \& O'SULLIVAN, S. E. 2019. A systematic review of cannabidiol dosing in clinical populations. Br J Clin Pharmacol.

MOODY, D. E. 2012. Marijuana Cannabis sativa L and Synthetic Cannabinoids. Medical Toxicology of Drug Abuse: Synthesized Chemicals and Psychoactive Plants. John Wiley \& Sons.

MORGAN, C. J., ROTHWELL, E., ATKINSON, H., MASON, O. \& CURRAN, H. V. 2010. Hyper-priming in cannabis users: a naturalistic study of the effects of cannabis on semantic memory function. Psychiatry Res, 176, 213-8.

MURMAN, D. L. 2015. The Impact of Age on Cognition. Semin Hear, 36, 111-21. 
NHS 1993. Scottish Intercollegiate Guidelines Network.

NLM, UNITED STATES NATIONAL LIBRARY OF MEDICINE PubMed [Online]. Available: www.ncbi.nlm.nih.gov/pubmed/.

NUSBAUM, A. T., WHITNEY, P., CUTTLER, C., SPRADLIN, A., HINSON, J. M. \& MCLAUGHLIN, R. J. 2017. Altered attentional control strategies but spared executive functioning in chronic cannabis users. Drug Alcohol Depend, 181, 116-123.

ORR, C., SPECHLER, P., CAO, Z., ALBAUGH, M., CHAARANI, B., MACKEY, S., D'SOUZA, D., ALLGAIER, N., BANASCHEWSKI, T., BOKDE, A. L. W., BROMBERG, U., BÜCHEL, C., BURKE QUINLAN, E., CONROD, P., DESRIVIÈRES, S., FLOR, H., FROUIN, V., GOWLAND, P., HEINZ, A., ITTERMANN, B., MARTINOT, J. L., MARTINOT, M. P., NEES, F., PAPADOPOULOS ORFANOS, D., PAUS, T., POUSTKA, L., MILLENET, S., FRÖHNER, J. H., RADHAKRISHNAN, R., SMOLKA, M. N., WALTER, H., WHELAN, R., SCHUMANN, G., POTTER, A. \& GARAVAN, H. 2019. Grey Matter Volume Differences Associated with Extremely Low Levels of Cannabis Use in Adolescence. J Neurosci, 39, 1817-1827.

ORWIN, R. G. 1983. A Fail-Safe N for Effect Size in Meta-Analysis. J. Edu. Stat, 8, 3.

PIUMATTI, G., MOORE, S. C., BERRIDGE, D. M., SARKAR, C. \& GALLACHER, J. 2018. The relationship between alcohol use and long-term cognitive decline in middle and late life: a longitudinal analysis using UK Biobank. J Public Health (Oxf), 40, 304311.

QUINTANA, S. M. \& MINAMI, T. 2006. Guidelines for Meta-Analysis of Counseling Psychology Research. Counseling Psychologist, 34, 38.

REZAPOUR, T., HATAMI, J., FARHOUDIAN, A., SOFUOGLU, M., NOROOZI, A., DANESHMAND, R., SAMIEI, A. \& EKHTIARI, H. 2015. NEuro COgnitive REhabilitation for Disease of Addiction (NECOREDA) Program: From Development to Trial. Basic Clin Neurosci, 6, 291-8.

ROMERO-SANDOVAL, E. A., KOLANO, A. L. \& ALVARADO-VÁZQUEZ, P. A. 2017. Cannabis and Cannabinoids for Chronic Pain. Curr Rheumatol Rep, 19, 67.

SALTHOUSE, T. A. 2009. When does age-related cognitive decline begin? Neurobiol Aging, 30, 507-14.

SCHREINER, A. M. \& DUNN, M. E. 2012. Residual effects of cannabis use on neurocognitive performance after prolonged abstinence: a meta-analysis. Exp Clin Psychopharmacol, 20, 420-429.

SCHULTE, M. T. \& HSER, Y. I. 2014. Substance Use and Associated Health Conditions throughout the Lifespan. Public Health Rev, 35.

SCOTT, J. C., SLOMIAK, S. T., JONES, J. D., ROSEN, A. F. G., MOORE, T. M. \& GUR, R. C. 2018. Association of Cannabis With Cognitive Functioning in Adolescents and Young Adults: A Systematic Review and Meta-analysis. JAMA Psychiatry, 75, 585-595.

SMITH, M. J., COBIA, D. J., REILLY, J. L., GILMAN, J. M., ROBERTS, A. G., ALPERT, K. I., WANG, L., BREITER, H. C. \& CSERNANSKY, J. G. 2015. Cannabis-related episodic memory deficits and hippocampal morphological differences in healthy individuals and schizophrenia subjects. Hippocampus, 25, 1042-51.

SMITH, M. J., COBIA, D. J., WANG, L., ALPERT, K. I., CRONENWETT, W. J., GOLDMAN, M. B., MAMAH, D., BARCH, D. M., BREITER, H. C. \& CSERNANSKY, J. G. 2014. Cannabis-related working memory deficits and associated subcortical 
morphological differences in healthy individuals and schizophrenia subjects. Schizophr Bull, 40, 287-99.

STROUP, D. F., BERLIN, J. A., MORTON, S. C., OLKIN, I., WILLIAMSON, G. D., RENNIE, D., MOHER, D., BECKER, B. J., SIPE, T. A. \& THACKER, S. B. 2000. Meta-analysis of observational studies in epidemiology: a proposal for reporting. Meta-analysis Of Observational Studies in Epidemiology (MOOSE) group. JAMA, 283, 2008-12.

SUTTON, A. J., DUVAL, S. J., TWEEDIE, R. L., ABRAMS, K. R. \& JONES, D. R. 2000. Empirical assessment of effect of publication bias on meta-analyses. BMJ, 320, 1574-7.

TAIT, R. J., MACKINNON, A. \& CHRISTENSEN, H. 2011. Cannabis use and cognitive function: 8-year trajectory in a young adult cohort. Addiction, 106, 2195-203.

TARAWNEH, R. \& HOLTZMAN, D. M. 2012. The clinical problem of symptomatic Alzheimer disease and mild cognitive impairment. Cold Spring Harb Perspect Med, 2, a006148.

THOMPSON, S. G. \& HIGGINS, J. P. 2002. How should meta-regression analyses be undertaken and interpreted? Stat Med, 21, 1559-73.

TSINGHUA-UNIVERSITY. CNKI [Online]. Available: http://oversea.cnki.net/.

VOLKOW, N. D., BALER, R. D., COMPTON, W. M. \& WEISS, S. R. 2014. Adverse health effects of marijuana use. N Engl J Med, 370, 2219-27.

WHO, WORLD HEALTH ORGANIZATION 2019. Cannabis - WHO [Online]. Available: https://www.who.int/substance_abuse/facts/cannabis/en/.

WINTERS, K. C. \& ARRIA, A. 2011. Adolescent Brain Development and Drugs. Prev Res, 18, 21-24. 


\section{Figure Captions}

\section{FIGURE 1: NEUROCOGNITIVE ASSOCIATIONS WITH CHRONIC CANNABIS USE: QUALITY OF REPORTING OF META-ANALYSIS (QUOROM): 2010-2018}

\section{FIGURE 2: COGNITIVE IMPULSIVITY FOREST PLOT}

Std diff = standard difference; $Z$ value = one sample Z statistic; $p$ value = probability that $Z$ statistics is significantly different than 0; lower limit = lower limit of the 95\% confidence interval for the effect size; upper limit = upper limit of the 95\% confidence interval for the effect size; IGT = lowa Gambling Task; CWIT = Color Word Interference Task; SOA = Stimulus Onset Asynchrony

\section{FIGURE 3: MOTOR IMPULSIVITY}

Std diff = standard difference; $Z$ value = one sample Z statistic; $p$ value = probability that $Z$ statistics is significantly different than 0; lower limit = lower limit of the 95\% confidence interval for the effect size; upper limit = upper limit of the 95\% confidence interval for the effect size; GST = Go-Stop Task; ST = Classical Stroop Task

\section{FIGURE 4: COGNITIVE FLEXIBILITY}

Std diff = standard difference; $Z$ value = one sample Z statistic; $p$ value = probability that $Z$ statistics is significantly different than 0; lower limit = lower limit of the 95\% confidence interval for the effect size; upper limit = upper limit of the 95\% confidence interval for the effect size; SCWT = Stroop Color Word Task; VF = Verbal Fluency; COWAT = Controlled Oral Word Association Test

\section{FIGURE 5: ATTENTION}

Std diff = standard difference $; Z$ value = one sample Z statistic; $p$ value = probability that $Z$ statistics is significantly different than 0; lower limit = lower limit of the 95\% confidence interval for the effect size; upper limit = upper limit of the 95\% confidence interval for the effect size; DS = Digit Span; CaST = Cannabis Stroop Task; RUFF = Ruff 2\&7; FACT = Flexible Attentional Control Task.

\section{FIGURE 6: SHORT-TERM MEMORY}

Std diff = standard difference; $Z$ value = one sample Z statistic; $p$ value = probability that $Z$ statistics is significantly different than 0; lower limit = lower limit of the $95 \%$ confidence interval for the effect size; upper limit = upper limit of the 95\% confidence interval for the effect size; HVLT = Hopkins Verbal Learning Test; CVLT = California Verbal Learning Test; RAVLT = Rey Auditory Verbal Learning Test; 2-BT = 2-Back Test

\section{FIGURE 7: LONG-TERM MEMORY}

Std diff = standard difference; $Z$ value = one sample $Z$ statistic; $p$ value = probability that $Z$ statistics is significantly different than 0; lower limit = lower limit of the $95 \%$ confidence interval for the effect size; upper limit = upper limit of the 95\% confidence interval for the effect size; HVLT = Hopkins Verbal Learning Test; CVLT = California Verbal Learning Test; RAVLT = Rey Auditory Verbal Learning Test 
FIGURE 1

NEUROCOGNITIVE ASSOCIATIONS WITH CHRONIC CANNABIS USE: QUALITY OF REPORTING OF

META-ANALYSIS (QUOROM): 2010-2018

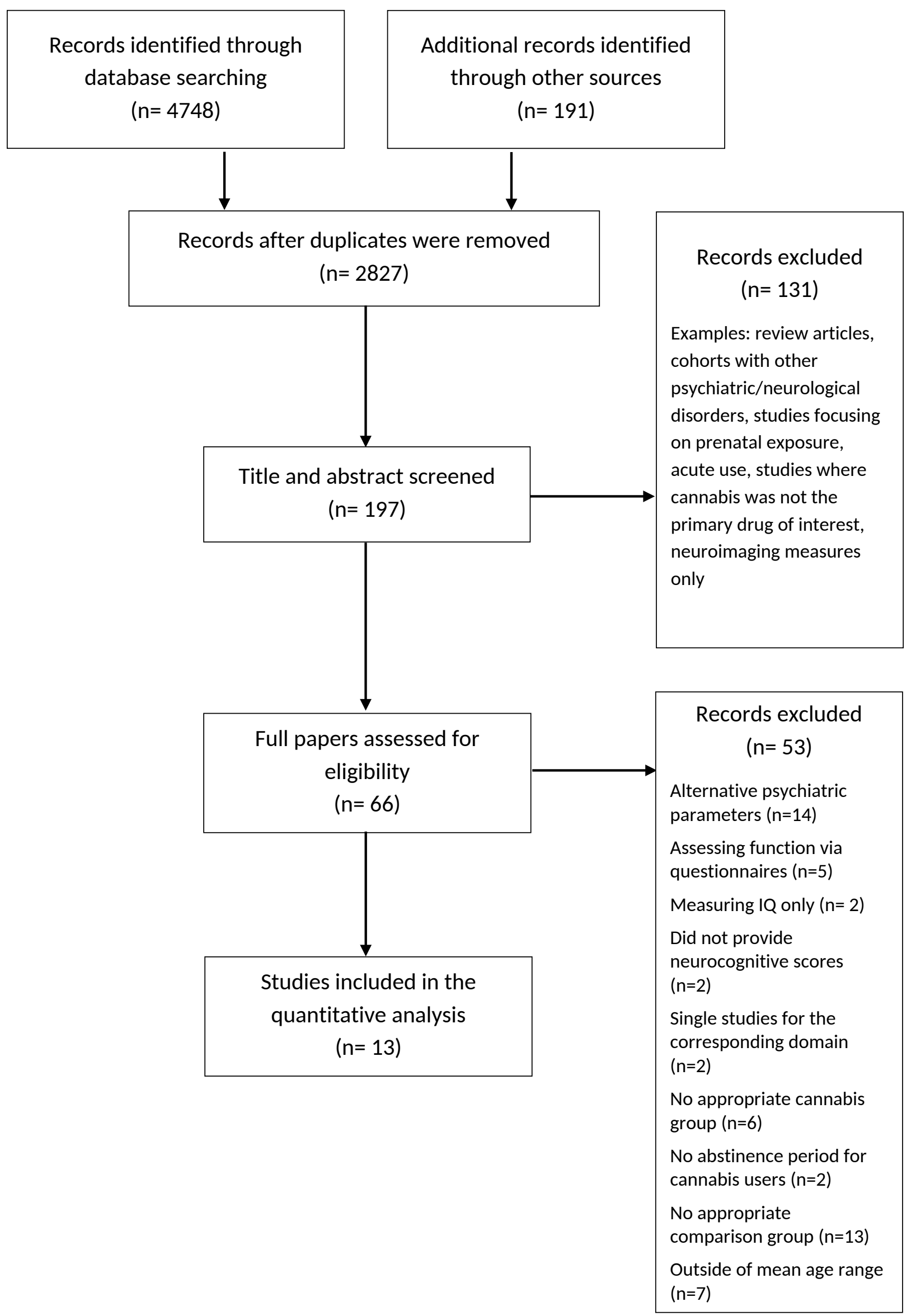


FIGURE 2

COGNITIVE IMPULSIVITY FOREST PLOT

Cognitive Impulsivity: Chronic Cannabis Users vs Comparision Group

\begin{tabular}{|c|c|c|c|c|c|c|c|c|c|c|c|c|}
\hline \multirow[t]{2}{*}{ Studyname } & \multirow[t]{2}{*}{ Outcome } & \multicolumn{7}{|c|}{ Statistics for each study } & \multicolumn{4}{|c|}{ Std diff in means and $95 \% \mathrm{Cl}$} \\
\hline & & $\begin{array}{l}\text { Std diff } \\
\text { in means }\end{array}$ & $\begin{array}{l}\text { Standard } \\
\text { error }\end{array}$ & Variance & $\begin{array}{l}\text { Lower } \\
\text { limit }\end{array}$ & $\begin{array}{c}\text { Upper } \\
\text { limit }\end{array}$ & Z-Value & p-Value & & & & \\
\hline Gonzalez et al 2012 & IGT & 0.071 & 0.175 & 0.031 & -0.273 & 0.415 & 0.404 & 0.686 & & & 1 & 1 \\
\hline Lisdahl et al 2012 & CWT & 0.087 & 0.267 & 0.071 & -0.436 & 0.611 & 0.327 & 0.743 & & & & \\
\hline Becker et al 2014 & IGT Good choice & 0.622 & 0.245 & 0.060 & 0.142 & 1.102 & 2.542 & 0.011 & & & & \\
\hline \multirow[t]{4}{*}{ Morgan et al 2010} & SOA \% errors & 0.500 & 0.236 & 0.056 & 0.037 & 0.963 & 2.116 & 0.034 & & & & \\
\hline & & 0.301 & 0.143 & 0.020 & 0.021 & 0.581 & 2.107 & 0.035 & & & & \\
\hline & & & & & & & & & -4.00 & -2.00 & 2.00 & 4.00 \\
\hline & & & & & & & & & & Favours Cannabis Users & Favours Comparis & \\
\hline
\end{tabular}

Note Std diff = standard difference; $Z$ value = one sample Z statistic; $p$ value = probability that $Z$ statistics is significantly different than 0; lower limit = lower limit of the 95\% confidence interval for the effect size; upper limit = upper limit of the 95\% confidence interval for the effect size; IGT = lowa Gambling Task; CWIT = Color Word Interference Task; SOA = Stimulus Onset Asynchrony 
FIGURE 3

MOTOR IMPULSIVITY FOREST PLOT

Motor Impulsivity: Chronic Cannabis Users vs Comparison Group

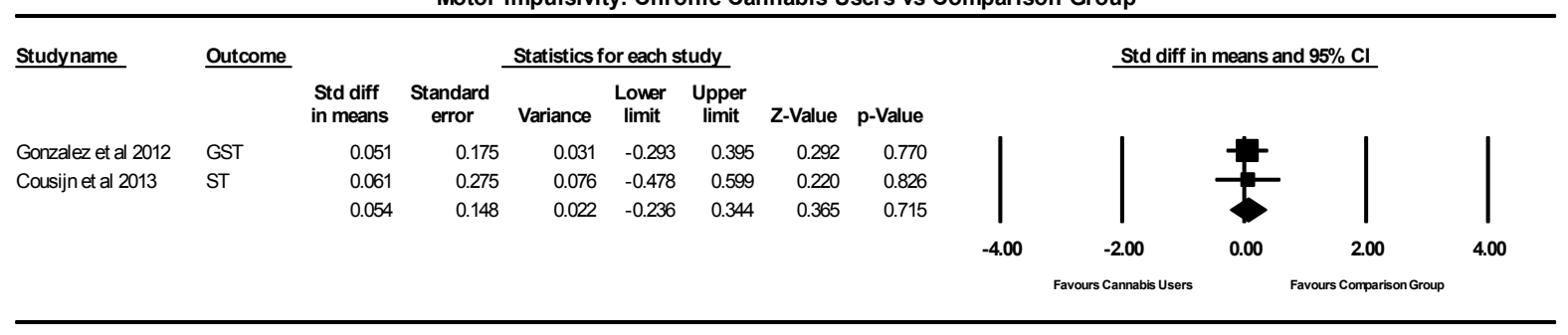

Note Std diff = standard difference; $Z$ value = one sample Z statistic; $p$ value = probability that Z statistics is significantly different than 0; lower limit = lower limit of the 95\% confidence interval for the effect size; upper limit = upper limit of the 95\% confidence interval for the effect size; GST = Go-Stop Task; ST = Classical Stroop Task 
FIGURE 4

COGNITIVE FLEXIBILITY FOREST PLOT

Cognitive Flexibility: Chronic Cannabis Users vs Comparison Group

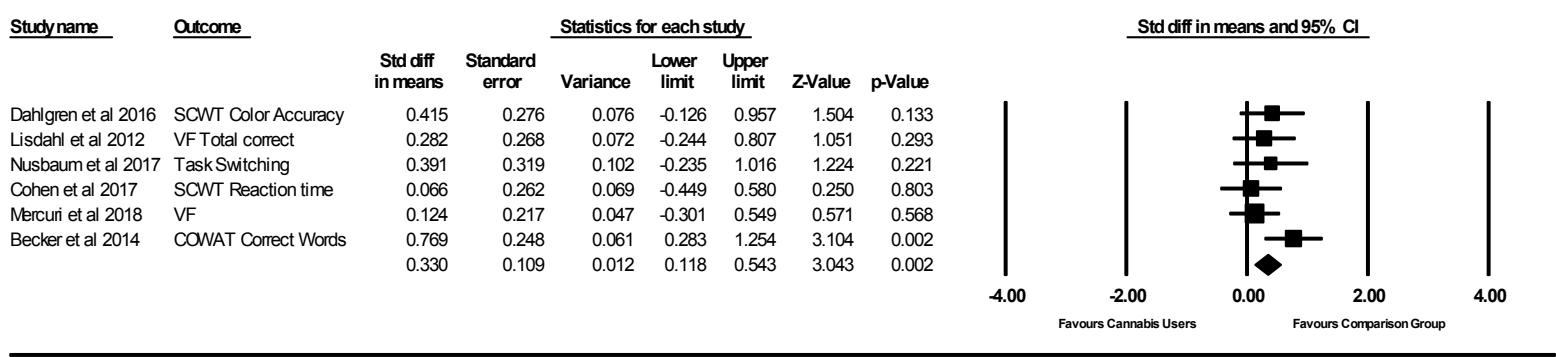

Note Std diff = standard difference; Z value = one sample Z statistic; $p$ value = probability that Z statistics is significantly different than 0; lower limit = lower limit of the 95\% confidence interval for the effect size; upper limit = upper limit of the 95\% confidence interval for the effect size; SCWT = Stroop Color Word Task; VF = Verbal Fluency; COWAT = Controlled Oral Word Association Test 
FIGURE 5

ATTENTION FOREST PLOT

Attention: Chronic Cannabis Users vs Comparison Group

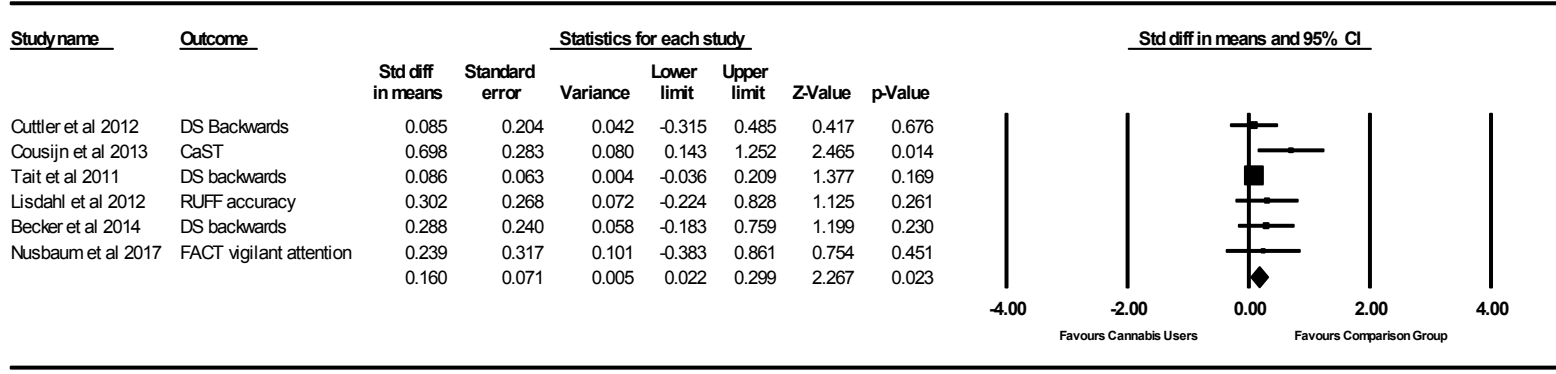

Note Std diff = standard difference; $Z$ value = one sample Z statistic; $p$ value = probability that Z statistics is significantly different than 0; lower limit = lower limit of the 95\% confidence interval for the effect size; upper limit = upper limit of the 95\% confidence interval for the effect size; DS = Digit Span; CaST = Cannabis Stroop Task; RUFF = Ruff 2\&7; FACT = Flexible Attentional Control Task. 
FIGURE 6

SHORT-TERM MEMORY FOREST PLOT

Short Term Memory: Chronic Cannabis Users vs Comparison Group

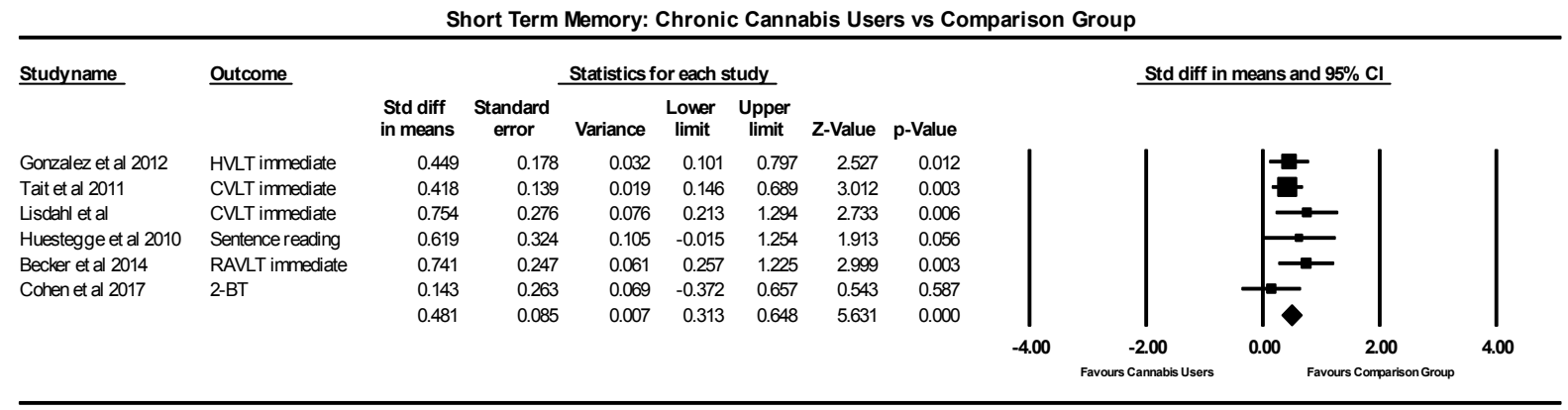

Note Std ditt = standard ditference; $\angle$ value = one sample $\angle$ statıstıc; $p$ value = probabılıty that $\angle$ statıstıcs IS sıgnıtıcantly different than 0; lower limit = lower limit of the 95\% confidence interval for the effect size; upper limit = upper limit of the 95\% confidence interval for the effect size; HVLT = Hopkins Verbal Learning Test; CVLT = California Verbal Learning Test; RAVLT = Rey Auditory Verbal Learning Test; 2-BT = 2-Back Test 
FIGURE 7

LONG-TERM MEMORY FOREST PLOT

Long Term Memory: Chronic Cannabis Users vs Comparison Group

\begin{tabular}{|c|c|c|c|c|c|c|c|c|c|c|c|c|}
\hline \multirow[t]{2}{*}{ Studyname } & \multirow[t]{2}{*}{ Outcome } & \multicolumn{7}{|c|}{ Statistics for each study } & \multicolumn{4}{|c|}{ Std diff in means and $95 \% \mathrm{Cl}$} \\
\hline & & $\begin{array}{l}\text { Std diff } \\
\text { in means }\end{array}$ & $\begin{array}{l}\text { Standard } \\
\text { error }\end{array}$ & Variance & $\begin{array}{c}\text { Lower } \\
\text { limit }\end{array}$ & $\begin{array}{l}\text { Upper } \\
\text { limit }\end{array}$ & Z-Value & p-Value & & & & \\
\hline Gonzalez et al 2012 & HVLT delayed & 0.394 & 0.177 & 0.031 & 0.047 & 0.741 & 2.225 & 0.026 & & 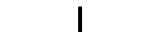 & 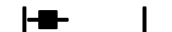 & 1 \\
\hline Tait et al 2011 & CVLT delayed & 0.340 & 0.138 & 0.019 & 0.068 & 0.611 & 2.454 & 0.014 & & & & \\
\hline Lisdahl et al 2012 & CVLT delyaed & 0.112 & 0.267 & 0.071 & -0.412 & 0.635 & 0.418 & 0.676 & & & & \\
\hline \multirow[t]{4}{*}{ Becker et al 2014} & RAVLT delayed & 0.922 & 0.251 & 0.063 & 0.429 & 1.414 & 3.666 & 0.000 & & & & \\
\hline & & 0.426 & 0.137 & 0.019 & 0.158 & 0.694 & 3.120 & 0.002 & & & & \\
\hline & & & & & & & & & -4.00 & -2.00 & 0.00 & 4.00 \\
\hline & & & & & & & & & & Favours Cannabis Users & Favours Comparis & \\
\hline
\end{tabular}

Note Std diff = standard difference; $Z$ value = one sample $Z$ statistic; $p$ value = probability that $Z$ statistics is significantly different than 0; lower limit = lower limit of the 95\% confidence interval for the effect size; upper limit = upper limit of the 95\% confidence interval for the effect size; HVLT = Hopkins Verbal Learning Test; CVLT = California Verbal Learning Test; RAVLT = Rey Auditory Verbal Learning Test 
TABLE 1

EXECUTIVE FUNCTIONS

\begin{tabular}{|c|c|c|c|}
\hline Main Domain & Subdomain & Definition & Tests \\
\hline \multirow{7}{*}{ IMPULSIVITY } & \multirow{3}{*}{ Cognitive Impulsivity } & $\begin{array}{l}\text { Ability to opt for larger delayed rewards over smaller } \\
\text { more immediate rewards }\end{array}$ & \\
\hline & & Decision-making under ambiguity & IGT, MFFT, BIS, DDT, CWIT, SOA \\
\hline & & Decision-making under risk & CGT, IGT, RDMT, GDT, BART \\
\hline & Non-Planning Impulsivity & $\begin{array}{l}\text { Ability to think ahead and actively search for an } \\
\text { appropriate solution }\end{array}$ & $\begin{array}{c}\text { TOL, SOC, ROCFT, PMT, TOH } \\
\text { WAIS-III (Block Design, Matrix Reasoning), SS, } \\
\text { SWM }\end{array}$ \\
\hline & \multirow{3}{*}{ Motor Impulsivity } & $\begin{array}{c}\text { Ability to suppress emotional, cognitive and } \\
\text { behavioural responses }\end{array}$ & \\
\hline & & Process required to stop a planned movement & AGN, SST, Go/NoGo, GST \\
\hline & & $\begin{array}{l}\text { Process required to suppress a salient but conflicting } \\
\text { stimulus while identifying less salient ones }\end{array}$ & ST \\
\hline
\end{tabular}




\begin{tabular}{|c|c|c|c|}
\hline \multirow{3}{*}{ FLEXIBILITY } & \multirow{3}{*}{ Cognitive Flexibility } & $\begin{array}{c}\text { Ability to shift avenues of thought and action in order } \\
\text { to perceive process and respond to situations in } \\
\text { different ways }\end{array}$ & \\
\hline & & $\begin{array}{l}\text { Ability to realign a behavioural predisposition to } \\
\text { altered contingencies }\end{array}$ & WCST, ST, IED, TMT, HSCT, MCST, SCWT, TS \\
\hline & & $\begin{array}{l}\text { Requires the intrinsic generation of responses or } \\
\text { alternatives }\end{array}$ & $\begin{array}{l}\text { COWAT, FAS, VF, RFFT, WAIS-III (Similarities), } \\
\text { RWT, DF }\end{array}$ \\
\hline COMPULSIVITY & & $\begin{array}{l}\text { The feeling that one has to perform an action, or the } \\
\text { inability to stop performing an action }\end{array}$ & IED \\
\hline COGNITION & Emotional Cognition & $\begin{array}{l}\text { Ability to recognize, process and respond to emotions } \\
\text { rapidly }\end{array}$ & EPT, FEIT, FEDT, DEERT, MET \\
\hline
\end{tabular}

AGN = Affective Go-NoGo; AM = Austine Maze; BADS = Behavioural Assessment of Dysexecutive Syndrome; BART = Balloon Analogue Risk Task; BIS = Barratt Impulsiveness Scale; BLC= Big Little Circle; CBT = Corsi Block Test; CGT = Cambridge Gambling Task; CLFT = Category and Letter Fluency Test; CWIT = Color Word Interference Task; COWAT = Controlled Oral Word Association Test; $C T T$ = Colour Trail Test; CVLT = California Verbal Learning Test; DEERT = Dynamic Emotional Expression Recognition Task; DDT = Delay Discounting Test; DF = Design Fluency; DS = Digit Span; EPT = Emotional Processing Task; FAS = Phonological Fluency Test; FEDT = Facial Emotion Discrimination Test; FEIT = Facial Emotion Identification Test; GDT = Game and Dice Test; GST = Go-Stop Task; HSCT = Hayling Sentence Completion Test; IED = Intra/Extra-Dimensional Set Shifting Task; IST = Information Sampling Test; IGT = Iowa Gambling Task; MFFT = Matching Familiar Figures; MCST = Maudsley Card Sorting Test; PASAT = Paced Auditory Serial Addition Task; PMT = Proteus Maze Test; RAVLT = Rey Auditory Verbal Learning Test; RDMT = Rogers Decision Making Task; ROCFT = Rey-Osterreith Complex Figure Test; RWFT = Regensburger Word Fluency Test; SCT = Logan Stop Change Task; SCWT = Stroop Color Word Task; SOA = Stimulus Onset Asynchrony; SOC = Stockings of Cambridge; SS = Spatial Span, SST = Stop Signal Test; SWM = Spatial Working Memory; ST = Stroop Test; TOH = Tower of Hanoi; TOL = Tower of London; TS = Stroop-like task switching; VF = Benton Verbal Fluency Test; WCST = Wisconsin Card Sorting Test; WAIS-R/III = Wechsler Adult Intelligence Scale -Revised/Third Edition; FAT = Test of Attentional Flexibility; MAT = Matrices for Intelligence Test; MET = Mind in the Eyes Test; RST3 = Multiple Choice under Stress; LL5 = Labyrinth of Lines to Measure Visual Structuring Performance. 
TABLE 2

ATTENTION

\begin{tabular}{|c|c|c|}
\hline Main Domain & Definition & Tests \\
\hline \multirow{6}{*}{ ATTENTION } & Arousal / Alertness & DSST \\
\hline & $\begin{array}{l}\text { Ability to reject irrelevant information } \\
\text { while attending to relevant input }\end{array}$ & TMT, TEA, ST, RT, SSRT, DR2, Q1, CaST, FACT, LCT \\
\hline & $\begin{array}{l}\text { Readiness to detect rarely and unpredictable occurring signals } \\
\text { over prolonged periods of time }\end{array}$ & PASAT, TOVA, TEA, CPT, FTT, ACT, SRT, RUFF \\
\hline & $\begin{array}{l}\text { Ability for individuals to hold information in mind and process; } \\
\text { need to process tasks simultaneously }\end{array}$ & \\
\hline & Attention span & CVLT, RAVLT \\
\hline & Reaction time or information processing speed & DSST, WAIS-III, DS, SDMT, DSY \\
\hline
\end{tabular}

ACT = Attentional Capture Task; CaST = Cannabis Stroop Task; CPT = Continuous Performance Test CVLT = California Verbal Learning Test; DS = Digit Span; DSST = Digit Symbol Substitution Test; DSY = Digit Symbol Substitution Test; DR2 = Simple Choice Reaction; FACT = Flexible Attentional Control Task; LCT = Letter Cancellation Test; FTT = Finger Tapping Test; PASAT = Paced Auditory Serial Addition Task; Q1= Attention under Monotonous Circumstances; RT = Reaction Time; RAVLT = Rey Auditory Verbal Learning Test; RUFF = Ruff 2\&7; SDMT = Symbol Digit Modality Test; SSRT = Stop Signal Reaction Time; SRT = Serial Reaction Time; TEA = Test of Everyday Attention; TMT = Trail Making Test; TOVA = Test of Variables of Attention; WAIS-III = Wechsler Adult Intelligence Scale. 
TABLE 3

LEARNING AND MEMORY

\begin{tabular}{|c|c|c|c|}
\hline Main Domain & Subdomain & Definition & Tests \\
\hline \multirow{5}{*}{$\begin{array}{l}\text { LEARNING AND } \\
\text { MEMORY }\end{array}$} & \multirow[b]{2}{*}{ Short-term Memory } & $\begin{array}{l}\text { Reproduction, recognition or recall of information directly } \\
\text { or some time after presentation }\end{array}$ & $\begin{array}{c}\text { LMT, RAVLT, CVLT, WAIS-III, DS, VRM, WMSR, } \\
\text { WRM, GNT, DFDBT, 2-BT, HVLT, WCST, VLT, } \\
\text { WPAT, ERT }\end{array}$ \\
\hline & & $\begin{array}{l}\text { Allow information to be evaluated and perhaps stored } \\
\text { longer through rehearsal and coding }\end{array}$ & $\begin{array}{c}\text { SWM, DMS, PRM, PAL, } \\
\text { BVRT, PAL, SRM, WMSR, RCFT, PASAT, WAIS-III, } \\
\text { BVMT, CCDT, 3D-BCM, CBT, WMS, SS, SR, SOS, } \\
\text { Free-Recall }\end{array}$ \\
\hline & \multirow{3}{*}{ Long-term Memory } & $\begin{array}{l}\text { Records details salient to individuals } \\
\text { Life. Needs conscious thinking "knowing that" }\end{array}$ & $\begin{array}{l}\text { PRM, SRM, CVLT, RAVLT, PAL, RCFT, WMSR, } \\
\text { WAIS-III, HVLT, VPMT, FPMT, RPMT, CPMT }\end{array}$ \\
\hline & & $\begin{array}{l}\text { Meaning of words and concepts or propositional } \\
\text { knowledge (facts) }\end{array}$ & RCFT, COWAT, GNT, WMSR, RBMT \\
\hline & & Does not need conscious thinking "knowing how" & \\
\hline
\end{tabular}

$B V M T-R=$ Brief Visuospatial Memory Test-Revised; BVRT = Benton Visual Retention Test; $C B T=$ Corsi Block Test; $C C D T=$ Colour Change Detection Task; COWAT = Controlled Oral Word Association Test; CPMT = Call-In Prospective Memory Test; CVLT = California Verbal Learning Test; DFDBT = Digit Forward and Digit Backwards Test; DMS = Delayed Matching to Sample; DS = Digit Span; ERT = Eye Reading Test; FPMT = Fruit Prospective Memory Test; GNT = Graded Name Test; HVLT = Hopkins Verbal Learning Test; LMT = Logical Memory Test; SRM = Spatial Recognition Memory; PAL = Paired Associate Learning; PASAT = Paced Auditory Serial Addition Task; PRM = Pattern Recognition Memory; RAVLT = Rey Auditory Verbal Learning Test; RBMT $=$ Rivermead Behavioural Memory Test; ROCFT = Rey Osterreith Complex Figure Test; RPMT = Reminder Prospective Memory Test; RRLET = Remote and Recent Life Event Test; SAVF =

Semantic Association of Verbal Fluency; SOMT = Six Object Memory Test; SOS = Self-Ordered Search; SR = Sentence Reading; SWM =Spatial Working Memory; SS = Spatial Span; 2-BT = Two Back Test; 3D-BCM = Three Dimensional Block Constitution Model; VLT = Verbal Learning Task; VPMT = Video-based Prospective Memory Task; VRM = Verbal Recognition Memory; WAIS-II = Wechsler Adult Intelligence Scale; WMS-III= Wechsler Memory Scale; WPAT = Wechsler Paired Associate Test; WRM = Word Recognition Memory; WSLT = Word Sequence Learning Test. 
TABLE 4

COMPARATOR GROUPS INCLUDED AND EXCLUDED IN THE META-ANALYSIS

Included comparator groups

Chronic/heavy cannabis smokers

Never or Minimal/Non-smokers

Excluded comparator groups

Cannabis-experimenters

Early-onset cannabis users

Remain light smokers

Former light smokers

Former heavy smokers

Always former

Cannabis users on stress tasks

Synthetic cannabis users

Recreational cannabis users 
TABLE 5

CHARACTERISTICS OF THE INCLUDED STUDIES

\begin{tabular}{|c|c|c|c|c|c|c|}
\hline Study & $\begin{array}{c}\text { Year of } \\
\text { Publication }\end{array}$ & Manuscript Title of Selected Study & $\mathbf{N}$ & $\begin{array}{c}\text { Group = } \mathrm{n}(\% \text { Male, Mean age } \\
{[\mathrm{SD}] \text { in years) }}\end{array}$ & Study Design & $\begin{array}{l}\text { Level of Evidence - } \\
\text { SIGN (variables) }\end{array}$ \\
\hline Huestegge et al. & 2010 & $\begin{array}{l}\text { Long-term effects of cannabis on eye } \\
\text { movement control in reading }\end{array}$ & 40 & $\begin{array}{l}\mathrm{CCU}=20(70.00 \%, 25.00[\mathrm{NR}]) \\
\mathrm{CG}=20(70.00 \%, 24.00[\mathrm{NR}])\end{array}$ & $\begin{array}{c}\text { Cross } \\
\text { Sectional }\end{array}$ & $2++$ \\
\hline $\begin{array}{l}\text { Bartholomew et } \\
\text { al. }\end{array}$ & 2010 & $\begin{array}{c}\text { Does cannabis use affect prospective } \\
\text { memory in young adults? }\end{array}$ & 90 & $\begin{aligned} \mathrm{CCU} & =45(44.40 \%, 19.00[5.00]) \\
\mathrm{CG} & =45(37.70 \%, 19.00[3.00])\end{aligned}$ & $\begin{array}{l}\text { Cross } \\
\text { Sectional }\end{array}$ & $\begin{array}{c}2+ \\
\text { (Alcohol) }\end{array}$ \\
\hline Morgan et al. & 2010 & $\begin{array}{l}\text { Hyper-priming in cannabis users: } a \\
\text { naturalistic study of the effects of cannabis } \\
\text { on semantic memory function }\end{array}$ & 74 & $\begin{array}{l}\mathrm{CCU}=36(60.00 \%, 26.37[9.63]) \\
\mathrm{CG}=38(59.50 \%, 26.24[10.73])\end{array}$ & $\begin{array}{l}\text { Cross } \\
\text { Sectional }\end{array}$ & $2++$ \\
\hline Tait et al. & 2011 & $\begin{array}{c}\text { Cannabis use and cognitive function: } 8 \text {-year } \\
\text { trajectory in a young adult cohort }\end{array}$ & 480 & $\begin{array}{l}C C U=60(70.00 \%, 22.50[1.50]) \\
C G=420(43.10 \%, 22.70[1.50])\end{array}$ & Longitudinal & $\begin{array}{l}2+ \\
\text { (Education, English } \\
\text { language status, gender) }\end{array}$ \\
\hline Cuttler et al. & 2012 & $\begin{array}{l}\text { Mechanisms underlying the link between } \\
\text { cannabis use and prospective memory }\end{array}$ & 96 & $\begin{array}{c}\mathrm{CCU}=48(52.08 \%, 20.42[2.52]) \\
\mathrm{CG}=48(20.87 \%, 19.71[2.59])\end{array}$ & $\begin{array}{l}\text { Cross } \\
\text { Sectional }\end{array}$ & $\begin{array}{l}2 \\
\text { (Alcohol, education, } \\
\text { English language status, } \\
\text { gender, IQ, other SU) }\end{array}$ \\
\hline Lisdahl and Price & 2012 & $\begin{array}{c}\text { Increased marijuana use and gender predict } \\
\text { poorer cognitive functioning in adolescents } \\
\text { and emerging adults }\end{array}$ & 59 & $\begin{array}{c}\mathrm{CCU}=23(44.00 \%, 21.20[2.80]) \\
\mathrm{CG}=36(50.00 \%, 20.70[2.80])\end{array}$ & $\begin{array}{l}\text { Cross } \\
\text { Sectional }\end{array}$ & $\begin{array}{c}2+ \\
\text { (Alcohol, other SU) }\end{array}$ \\
\hline Gonzalez et al. & 2012 & $\begin{array}{c}\text { Performance of young adult cannabis users } \\
\text { on neurocognitive measures of impulsive } \\
\text { behavior and their relationship to } \\
\text { symptoms of cannabis use disorders }\end{array}$ & 130 & $\begin{array}{l}C C U=65(65.00 \%, 20.80[1.80]) \\
C G=65(51.00 \%, 20.30[2.00])\end{array}$ & $\begin{array}{l}\text { Cross } \\
\text { Sectional }\end{array}$ & $\begin{array}{c}2+ \\
\text { (Alcohol, tobacco) }\end{array}$ \\
\hline
\end{tabular}




\begin{tabular}{|c|c|c|c|c|c|c|}
\hline Cousijn et al. & 2013 & $\begin{array}{l}\text { Cannabis dependence, cognitive control } \\
\text { and attentional bias for cannabis words }\end{array}$ & 53 & $\begin{aligned} \mathrm{CCU} & =27(70.00 \%, 24.00[2.80]) \\
\mathrm{CG} & =26(62.00 \%, 25.30[2.60])\end{aligned}$ & $\begin{array}{l}\text { Cross } \\
\text { Sectional }\end{array}$ & $\begin{array}{c}2+ \\
\text { (Alcohol) }\end{array}$ \\
\hline Becker et al. & 2014 & $\begin{array}{l}\text { Neurocognition in college-aged daily } \\
\text { marijuana users }\end{array}$ & 70 & $\begin{array}{c}\mathrm{CCU}=35(63.90 \%, 19.52[0.62]) \\
\mathrm{CG}=35(37.10 \%, 19.40[0.93])\end{array}$ & $\begin{array}{c}\text { Cross } \\
\text { Sectional }\end{array}$ & $\begin{array}{c}2 \\
\text { (Age, gender) }\end{array}$ \\
\hline Dahlgren et al. & 2016 & $\begin{array}{l}\text { Marijuana use predicts cognitive } \\
\text { performance on tasks of executive function }\end{array}$ & 76 & $\begin{array}{c}\mathrm{CCU}=44(84.09 \%, 24.14[6.75]) \\
\mathrm{CG}=32(62.50 \%, 24.22[6.46])\end{array}$ & $\begin{array}{l}\text { Cross } \\
\text { Sectional }\end{array}$ & $\begin{array}{c}2+ \\
\text { (Alcohol) }\end{array}$ \\
\hline Cohen et al. & 2017 & $\begin{array}{l}\text { The effects of synthetic cannabinoids on } \\
\text { executive function }\end{array}$ & 83 & $\begin{aligned} \mathrm{CCU} & =42(52.00 \%, 27.45[5.35]) \\
\mathrm{CG} & =41(54.00 \%, 25.56[3.03])\end{aligned}$ & $\begin{array}{l}\text { Cross } \\
\text { Sectional }\end{array}$ & $\begin{array}{c}2 \\
\text { (Education, tobacco) }\end{array}$ \\
\hline Nusbaum et al. & 2017 & $\begin{array}{c}\text { Altered attentional control strategies but } \\
\text { spared executive functioning in chronic } \\
\text { cannabis users }\end{array}$ & 40 & $\begin{array}{l}\mathrm{CCU}=20(75.00 \%, 25.35[8.71]) \\
\mathrm{CG}=20(40.00 \%, 25.25[5.57])\end{array}$ & $\begin{array}{l}\text { Cross } \\
\text { Sectional }\end{array}$ & $\begin{array}{c}2 \\
\text { (gender) }\end{array}$ \\
\hline Mercuri et al. & 2018 & $\begin{array}{l}\text { Episodic foresight deficits in regular, but } \\
\text { not recreational, cannabis users }\end{array}$ & 91 & $\begin{aligned} \mathrm{CCU} & =34(45.00 \%, 24.70[3.9]) \\
\mathrm{CG} & =57(45.00 \%, 21.30[3.5])\end{aligned}$ & $\begin{array}{l}\text { Cross } \\
\text { Sectional }\end{array}$ & $\begin{array}{c}2 \\
\text { (Age, alcohol) }\end{array}$ \\
\hline
\end{tabular}

CCU = Chronic Cannabis Users; CG = Comparator group; $N$ = Total number of participants; \% = Percentage; SD = Standard Deviation; SU = Substance users; SIGN= Scottish Intercollegiate Guidelines Network

Level of evidence 2: unmatched; 2+: matched on demographic variables; $2++:$ matched on behavioural and demographic variables; $2^{*}$ : longitudinal measurements; $2+{ }^{*}$ matched with longitudinal study (using Scottish Intercollegiate Guidelines Network - SIGN) 
TABLE 6

CANNABIS USE CHARACTERISTICS AND TESTS ADMINISTERED

\begin{tabular}{|c|c|c|c|c|c|c|}
\hline Study & $\begin{array}{l}\text { Mean Dose and/or Mean } \\
\text { Frequency of CCU }\end{array}$ & $\begin{array}{c}\text { Duration of CCU / } \\
\text { Age of Onset in years }\end{array}$ & $\begin{array}{l}\text { Period of non-use } \\
\quad(C C U) \text { in days }\end{array}$ & $\begin{array}{l}\text { Period of non-use } \\
\text { (CG) in days }\end{array}$ & $\begin{array}{l}\text { Neurocognitive } \\
\text { Tests }\end{array}$ & $\begin{array}{l}\text { Neurocognitive } \\
\text { Domains }\end{array}$ \\
\hline $\begin{array}{l}\text { Huestegge et al., } \\
\qquad 2010\end{array}$ & $\begin{array}{l}10.5 \text { joints per week, } \\
3500 \text { joints in lifetime }\end{array}$ & $\begin{array}{l}9.0 \text { years / } \\
14-16 \text { years old }\end{array}$ & More than 1 day & Never used CN & ERT & LM \\
\hline $\begin{array}{l}\text { Bartholomew et } \\
\text { al., } 2010\end{array}$ & 2 joints per week & $\begin{array}{l}3.0 \text { years / } \\
\text { NR }\end{array}$ & 10.5 days & Never used CN & VPMT & LM \\
\hline $\begin{array}{l}\text { Morgan et al., } \\
2010\end{array}$ & $\begin{array}{l}2.3 \text { joints per SM, } \\
12.8 \text { days per month }\end{array}$ & $\begin{array}{l}\text { 7.6 years / } \\
\text { NR }\end{array}$ & 2.2 days & 414.1 days & SOA & $\mathrm{EF}$ \\
\hline Tait et al., 2011 & More than 1 SM per week & $\begin{array}{l}\text { NR / older than } 16 \\
\text { years old }\end{array}$ & More than 0.5 day & Never used CN & CVLT, DS, SDMT & A, LM \\
\hline $\begin{array}{l}\text { Cuttler et al., } \\
\qquad 2012\end{array}$ & $\begin{array}{c}\text { More than } 3 \text { SM per week for } \\
\text { at least a year }\end{array}$ & NR & More than 0.5 day & Never used CN & $\begin{array}{l}\text { DS, RAVLT, FPMT, } \\
\text { RPMT, CPTM }\end{array}$ & A, LM \\
\hline $\begin{array}{l}\text { Lisdahl and Price, } \\
\qquad 2012\end{array}$ & $\begin{array}{l}1014 \text { joints in lifetime, } \\
208 \text { SM per year }\end{array}$ & $\begin{array}{c}\mathrm{NR} / \\
15.0 \text { years old }\end{array}$ & 50.0 days & $\begin{array}{l}\text { Less than } 10 \mathrm{CN} \text { uses in } \\
\text { past year, less than } 50 \\
\mathrm{CN} \text { uses in a lifetime }\end{array}$ & $\begin{array}{l}\text { RUFF, CVLT, TMT, } \\
\text { VF, DF, CWIT }\end{array}$ & $\begin{array}{l}\text { A, EF, } \\
\text { LM }\end{array}$ \\
\hline $\begin{array}{l}\text { Gonzalez et al., } \\
2012\end{array}$ & $\begin{array}{l}60 \text { SM past year, } \\
6 \text { SM past month }\end{array}$ & $\begin{array}{l}5.0 \text { years / } \\
15.6 \text { years old }\end{array}$ & 3.0 days & 720.0 days & $\begin{array}{c}\text { IGT, BART, GST, } \\
\text { HVLT }\end{array}$ & $\mathrm{EF}, \mathrm{LM}$ \\
\hline $\begin{array}{l}\text { Cousijn et al., } \\
\qquad 2013\end{array}$ & $\begin{array}{c}3.8 \text { grams and } 5.1 \text { SM per } \\
\text { week }\end{array}$ & $\begin{array}{c}\text { NR / } \\
14.9 \text { years old }\end{array}$ & 2.8 days & 837.4 days & ST, CaST & $A, E F$ \\
\hline
\end{tabular}




\begin{tabular}{|c|c|c|c|c|c|c|}
\hline $\begin{array}{l}\text { Becker et al., } \\
\quad 2014\end{array}$ & $\begin{array}{l}\text { 10.2 hits per day, } \\
334.4 \text { days per year, } \\
25.9 \text { days per month }\end{array}$ & $\begin{array}{c}15.2 \text { years / } \\
13-17 \text { years old }\end{array}$ & More than 0.5 day & $\begin{array}{c}\text { Less than } 10 \mathrm{CN} \text { uses in } \\
\text { a lifetime }\end{array}$ & $\begin{array}{c}\text { TOL, IGT, DSY, LCT, } \\
\text { DS, SS, SR, SOS, } \\
\text { SDRT, FTT, COWAT, } \\
\text { RAVLT, DS }\end{array}$ & A, EF, LM \\
\hline $\begin{array}{l}\text { Dahlgren et al., } \\
\qquad 2016\end{array}$ & $\begin{array}{c}6.30 \text { grams and } 14.3 \mathrm{SM} \text { per } \\
\text { week }\end{array}$ & $\begin{array}{c}6.3 \text { years / } 18.1 \text { years } \\
\text { old }\end{array}$ & More than 0.5 day & $\begin{array}{c}\text { Less than } 15 \mathrm{CN} \text { use in a } \\
\text { lifetime }\end{array}$ & ST, WCST & $\mathrm{EF}$ \\
\hline Cohen et al., 2017 & NR & NR & $\begin{array}{c}(78.6 \%)<7 \text { days, } \\
(19 \%)>7 \text { days, } \\
(2.4 \%)>30 \text { days }\end{array}$ & 365.0 days & $\begin{array}{l}\text { CaST, 2-BT, } \\
\text { Free-Recall }\end{array}$ & $A, L M$ \\
\hline $\begin{array}{c}\text { Nusbaum et al., } \\
2017\end{array}$ & 26.70 days per month & $\begin{array}{c}7.0 \text { years / } 15.97 \\
\text { years old }\end{array}$ & More than 0.5 day & 365.0 days & FACT, TS & A, EF \\
\hline $\begin{array}{l}\text { Mercuri et al., } \\
2018\end{array}$ & NR & 17.2 years old & More than 1 day & Never used CN & TMT, HSCT, VF & EF \\
\hline
\end{tabular}

CCU = Chronic Cannabis Users; CG = Comparator Groups; SM = Smoking Episodes; $C N$ = Cannabis; NR = Not Reported; ERT = Eye Reading Test; VPMT = Video-based Prospective Memory Test; SOA = Stimulus Onset Asynchrony; CVLT = California Verbal Learning Test; DS = Digit Span; SDMT = Symbol Digit Modality Test; RAVLT = Rey Auditory Verbal Learning Test; FPMT = Fruit Prospective Memory Test; RPMT = Reminder Prospective Memory Test; $C P M T=$ Call-In Prospective Memory Test; RUFF $=$ Ruff $2 \& 7$ Test; TMT $=$ Trail Making Test; VF $=$ Verbal Fluency; DF = Design Fluency; CWIT = Color Word Inhibition Test; IGT = lowa Gambling Task; BART = Balloon Analog Risk Task; GST = Go-Stop Task; HVLT = Hopkins Verbal Learning Test; ST = Stroop Test; CaST = Cannabis Stroop Task; TOL = Tower of London; DSY = Digit Symbol Substitution Test; LCT = Letter Cancellation Test; SS = Spatial Span; SR = Spatial Recognition; SOS = Self-Ordered Search; SDRT = Spatial Delayed Response Task; FTT = Finger Tapping Test; COWAT = Controlled Oral Word Association Test; WCST = Wisconsin Card Sorting Test; 2-BT = Two-Back Test; FACT = Flexible Attentional Control Task; HSCT = Hayling Sentence Completion Test; A = Attention; EF = Executive Function; LM = Learning \& Memory; TS = Stroop-like task switching. 
TABLE 7

POOLED EFFECT SIZE OF EACH NEUROCOGNITVE DOMAIN

\begin{tabular}{|c|c|c|c|c|c|c|c|c|c|c|c|c|}
\hline \multirow[b]{2}{*}{ Neurocognitive Domains } & \multirow[b]{2}{*}{$\mathbf{N}$} & \multirow[b]{2}{*}{ Studies } & \multicolumn{4}{|c|}{ Effect size and $95 \%$ Confidence Interval } & \multicolumn{2}{|c|}{$\begin{array}{l}\text { Test for Null } \\
\text { (2 fail) }\end{array}$} & \multicolumn{3}{|c|}{ Heterogeneity } & \multirow{2}{*}{\begin{tabular}{l}
\multicolumn{1}{c}{ Bias } \\
Fail \\
Safe N
\end{tabular}} \\
\hline & & & Effect size & SE & Lower limit & Upper limit & Z & P for $Z$ & Q & P for $Q$ & $\mathbf{I}^{2}$ & \\
\hline Cognitive Impulsivity & 159 & 4 & 0.30 & 0.14 & 0.02 & 0.58 & 2.11 & $0.04^{*}$ & 4.76 & 0.19 & 36.97 & 4 \\
\hline Motor Impulsivity & 92 & 2 & 0.05 & 0.15 & -0.24 & 0.34 & 0.37 & 0.72 & 0.001 & 0.98 & 0.00 & $\mathrm{~N} / \mathrm{P}$ \\
\hline Non-Planning Impulsivity & 35 & 1 & N/A & N/A & N/A & N/A & N/A & N/A & $\mathrm{N} / \mathrm{A}$ & N/A & N/A & N/A \\
\hline Cognitive Flexibility & 168 & 6 & 0.33 & 0.11 & 0.12 & 0.54 & 3.04 & $0.002^{* *}$ & 5.22 & 0.39 & 4.29 & 10 \\
\hline Attention & 810 & 6 & 0.16 & 0.07 & 0.02 & 0.30 & 2.27 & $0.023^{*}$ & 5.52 & 0.36 & 9.48 & 9 \\
\hline Short Term Memory & 236 & 6 & 0.48 & 0.08 & 0.31 & 0.65 & 5.63 & $0.000^{*}$ & 4.17 & 0.53 & 0.00 & 44 \\
\hline Long Term Memory & 199 & 4 & 0.43 & 0.14 & 0.16 & 0.69 & 3.12 & $0.002^{* *}$ & 5.65 & 0.13 & 46.92 & 16 \\
\hline Emotional Cognition & 30 & 1 & N/A & N/A & N/A & N/A & N/A & $\mathrm{N} / \mathrm{A}$ & N/A & N/A & $\mathrm{N} / \mathrm{A}$ & N/A \\
\hline
\end{tabular}

$P=$ Significance ${ }^{*}$ significant at the $p<0.05$ level; ${ }^{* *}$ significant at the $p<0.01$ level; $N=$ Total number of studies; N/A = Data is not available to perform a meta-analysis as one needs more than 1 study to determine effect size; N/P = Not possible as one needs more than 2 studies to determine publication bias. 
